Note:

\title{
The Case for Land Reforms
}

\section{Rashed Rahman}

This article will attempt to answer the question why the redistribution of land ownership (i.e. land reform) is important and even necessary for our society's progress and development. Why there remains a crying need to concretely study the question of agrarian land ownership and all it implies in terms of political and economic power distribution and its social fallout in the rural milieu. Let us begin with an examination of how the present land ownership patterns originated and evolved.

A discussion of the pattern of agrarian land ownership must necessarily take as its main focus the areas where agriculture is the mainstay. That inevitably means the provinces of Punjab and Sindh. The other two provinces, NWFP and Balochistan, with the exception of some relatively limited areas where canal fed or barani cultivation exists, have economies that are mixed pastoral/agricultural, an economic base reflective of their surviving tribal structures.

Punjab and Sindh, being the inheritors of ancient riverine civilisations, did not always have the dominant character of perennially irrigated agricultural areas. The traditional system of drawing the waters of the rivers for irrigation relied on relatively primitive canals or seasonal flood inundation of areas lying along the course of the rivers (sailaba lands). In addition, wells drawing on the aquifer were widespread, especially in Punjab where the ground water level was easier reached. This ancient system, which had not changed radically in its essentials for thousands of years, was uprooted and shaken up on the advent of British colonialism.

Sindh was annexed by the British in 1842, Punjab in 1848 (which at that time included the Sikh Empire-controlled areas later designated the NWFP province). Having consolidated their rule, the British embarked on what was to prove historically the most ambitious reconfiguration of agriculture on the basis of a network of canals to provide perennial irrigation. The colonialists' purpose was not, as they sought to justify it, the ostensible welfare of their recently conquered subjects. A number of strategic political and economic objectives were sought to be achieved by this 'investment' (which was paid for, both directly and indirectly, from the loot of native resources). 
The canal colonies, as the Doabas and river banks cleared of forest came to be called, apart from whatever locals' came to benefit from colonial policy, were the sites for settlement of large numbers of people brought in from other areas of the same, and even other provinces. This was intended to create a class of yeoman peasantry' and large landowners, rewarded with land grants for loyalty to the British, past and future. In the process, the pastoralist tribes that inhabited these previously 'wild' lands were marginalised and some of them brought to the point of extinction. Riverine communities such as the Mohanas who relied on fishing and the Mirbahars who plied water transport were relegated to economic deprivation and even ruin once the natural ecology of the rivers was disturbed by canals and barrages.

The settlement policy of the British overturned the traditional dominant system of land ownership which rested on property rights being vested in the sovereign, the State. Private property in land was historically the exception rather than the rule. Jagirdars and Zamindars held sway over their flefdoms at the pleasure of the Court. No inherited rights devolved to their heirs and successors, except at the pleasure of the King. Starting from Bengal, their first conquest, the British incrementally instituted Permanent Settlements (of ownership rights and rates of revenue payable to the colonial administration) in all the territories they conquered, which made private property in land the dominant mode for the first time in the Subcontinent's long history. The newly created large landowning feudal elite was born out of this transformation. It soon set about overturning the traditional natural rights to common lands such as shamiloat.

Increased revenue from the irrigation water supplies (abiana) and agricultural production boosted by the perennial irrigation system was another colonial objective. Revenue collection in money terms helped to accelerate the transformation of a largely barter based rural economy to a cash economy. In the process, there occurred an incremental erosion and final demise of traditional village self-sufficiency based on barter exchange between agriculturists, pastoralists and artisans. The emergence of a cash economy and production of surpluses in agricultural goods led to the development of mandi (market) towns. Artisans flocked to these new mandi towns and further abroad to cities, helping to fuel the emergence of urban commercial and artisan classes, whose products and goods now began to filter back into the villages. This process has transformed the face of rural Punjab and Sindh and appears set to continue at an accelerated pace as urbanisation and the spread of communications and infrastructure brings the villages increasingly into the mainstream of economic life. 
The irrigation system inherited from British times was constructed The irrigation system inherited from British times was constructed between 18 9 and 1939. The protects involved major engineering works. It is estimated that some 500,000 people participated in this construction in the last two decades of the 19th century alone. Since independence, some more canals were constructed between 1955 and 1962. After independence, a dispute arose between Pakistan and India concerning the division of waters of what had hitherto been commonly shared river waters and the canal network flowing out of them. This was finally resolved through the Indus Basin Water Treaty of 1960, according to which the eastern Indus tributaries, the Ravi, Beas and Sutle) were awarded to India, the westerly rivers, Indus, Jehium, Chenab, to Pakistan. To replace the canals originating from the lost eastern rivers, a system of inter-river link canals and storage reservoirs was to be constructed. The two largest of these reservoirs were the Mangia Dam on the Jehium (1967) and the Tarbela Dam on the Indus (1974). In addition, the Chashma Barrage on the Indus was completed in 1971 .

Further major reservoirs have not been built, although the Ghazi Barotha Project under construction utilises sluice technology to provide irrigation water and generate power without the need for a large reservoir of the Mangia or Tarbela type. The planned Kalabagh Dam remains mired in controversy.

Disputes between and within provinces over water rights have been a fact of life for some time. As pressure on land to produce increasing amounts of food and other agricultural products to feed industry and a burgeoning population growing at 3.1 per cent a year increase, these disputes will most likely get uglier. At present, 74 per cent of the water of the Indus is withdrawn along its course to the Arabian Sea. The Indus Basin canal network is considered amongst the most extensive in the world. But it has proved a mixed blessing because seepage from unlined canals over the past 140 years or so has created the twin problems of water-logging and salinity that is destroying more and more acreage of productive farmland every year (one estimate has it this is in the region of 100,000 acres annually). Riverine forests are denuding because of these phenomena, causing erosion along banks and increased silting of river beds, raising them to heights which make frequent floods a near certainty.

As if the depredations produced by man-made irrigation systems are not enough, urbanisation, housing, roads, industries and other infrastructure is eating up farmland. Between 1981 and 1990, Punjab and Sindh lost 3.3 million acres of farmland to these 'encroachments'. Total farm area in these two provinces has shrunk from 49.2 million acres in 1972 to 
47.6 million acres in 1990. Decreasing land productivity. loss of farmland to water-logging, salinity and alternative use, all these are raising a neoMalthusian spectre of our not being able to feed our people. Increasing imports of necessary edibles also has a limit, considering our strained resources (wheat imports this year are of the magnitude of 4 million tonnes, estimated to cost Rs. 40 billion or $\$$ I billion out of the total food imports of Rs. 80 billion or $\$ 2$ billion. The rupee cost of these imports will rise after the recent devaluation of the rupee by at least an equivalent $8.71 \%$ ).

Self-sufficiency in food is eluding our grasp and becoming more and more a distant dream. One reason why critics of the present agrarian land ownership structure have argued from time to time that we should correct the anomaly of absentee landlordism which is inefficient, and redistribute land in recognition of the inverse relationship between size of farm and productivity, is because they rely on the example of all countries which have made, or are on the verge of making, the transition from pre-industrial to industrialised economies. All such cases either traditionally had small farm size distribution, or carried out land reform before they could emerge into the light of day as modern economies.

There are of course other rationales for land redistribution, such as equity and overcoming the baleful influence of feudalism on our polity and society.

\section{Agrarian reform efforts}

Pakistan inherited an agricultural land tenure system which was inherently iniquitous. This was the result of a high degree of concentration of land ownership, absentee landlordism, insecurity of tenure for tenants cultivating on the basis of share-cropping, and the extraction by landlords of excessive surplus through batai, abwab and begar labour (levies above and beyond customary practice). In today's Pakistan, the large landowning rentier class has, because of its control of one of the most basic and important means of production, agricultural land, exercised a baleful influence not only over the lives of the peasantry, but also over polity and society.

The degree of concentration of land ownership at the time of Partition and the independence of the country can be gauged from the fact that in West Punjab, out of 13.5 lakh landowners, more than 9 lakh owned less than 5 acres, 11.3 lakh owned less than 10 acres, 1.81 lakh owned between 10 to 50 acres, and only 0.656 lakhs owned more than 50 acres. In terms of acreage, of a total 146 lakh acres, these categories enumerated above owned 18, 34, 21.5, and 14.5 lakh acres respectively. In other words, 
67 per cent of landowners held 12 per cent of the land at one end of the scale, while 4.86 per cent of landowners held almost 10 per cent of the land at the other end of the scale, with 25 per cent landowners in the middle holding 26 per cent of the total cultivated area. Similar conditions were found in NWFP, where out of a total cultivated area of 25.25 lakh acres, about 47 per cent was owned by large owners, 42 per cent by peasant proprietors (khudkasht malikan) and the rest by tenants possessing occupancy rights. Balochistan, or at least its settled districts (Quetta, Pishin, Shahrig, Sinjawi), exhibited a predominant pattern of peasant proprietors. In Sindh, however, the overwhelming cultivable area was leased out to tenantsat-will (i.e. the landlord's will).

Despite the fact that even before independence, the need for a reform of the landownership pattern and tenancy regime had been acutely felt, especially in Sindh, the province most dominated by feudal large estates, and was followed by numerous studies and three land reforms, the situation has not changed essentially from what we inherited in 1947, marginal redistribution of land and tenant protection legislation notwithstanding. The thrust of all reform efforts has been to bring in change from above in a manner calculated to do least damage to feudal hegemony. Ceilings on land holdings and rules to mitigate the abuse by landlords against their weaker tenants have failed to scratch the surface of the feudal order. An economically captive peasantry provides the hereditary' political constituencies for the overwhelming number of feudal members in the Assemblies.

\section{Ayub and Bhuttos land reforms}

When Ayub Khan imposed martial law in 1958 with a 'modernising' thrust, land reform was one of the major policy decisions his government took for the merged province of West Pakistan under the One Unit scheme (East Pakistan having already carried out land reform in the early 50s), with the blessings of our Western mentors. However, the 'modernising' tendency in Ayub Khan's regime was necessarily subject to the limitations of its authors' philosophy. A thoroughgoing reform in order to break the back of feudalism was neither the intent nor the end result of the policy. Whatever the military's views regarding the mess the (1argely feudal) politicians had led the country into, the regime still had use for this species. The landlord politicians (or some faction from them) would again be useful when the regime civilianised its face. Major concessions and loopholes/lacunae were therefore allowed the large landowners, which had the effect of producing no more than a bare scratching of the surface of land ownership concentration. 
Only 2.5 million acres ( 3 per cent of the total culturable area) were resumed; 2.3 million acres were distributed amongst 183,371 tenants and small owners. Tenancy protection was practiced more in the breach because of the overwhelming influence of the large landowners in the rural milieu.

The 1960s became the decade of the Green Revolution, involving accelerated mechanisation, scientific inputs of improved seed, fertiliser, pesticides etc, to enhance productivity. This 'revolution' was based on an elite farmer strategy, on whom hopes for enhanced production rested. But whereas in East Punjab (India) the formula was applied in a structure in which large landholdings had already become a thing of the past (India carried out its first land reforms in the early 1950s) and the small owner 25 acres or so) took to the new technologies and methods like a duck to water, leading to yields which even today are three times ours, in Pakistan the formula was being applied in unfavourable ground in the presence of large landed estates. Productivity did increase, but its benefits flowed to the large landowners, who now began to evict tenants and resume lands in order to reap the benefits of mechanised self-cultivation that the new technology offered. The tenancy protection laws failed to prevent this eviction for the obvious reasons that the tenants could not combat the influence and power of the landlord. This mass of humanity, thrown off the land they had tilled for generations, began to filter to the towns and cities in search of livelihood. Thus began our era of slum dwellings (katchi abadis) in all major cities, which swelled the urban populace at a rate twice that of the national population growth rate. The result today is the collapse of urban services under this burgeoning pressure. A veritable demographic revolution has been set in motion which is likely to see the shift of a majority of the population into urban settlements within a decade.

Under the cover of being the first civilian Chief Martial Law Administrator in the country, Bhutto promulgated Martial Law Regulation 115 on March 1, 1972 to carry out land reforms. MLR 115 specified a ceiling of 150 acres irrigated and 300 acres unirrigated land, or an area equal to 15,000 PIUs. Because of the PIU formula, in practice the actual ceiling for a tractor/tubewell owner worked out to 466 acres in Punjab and 560 acres in Sindh. If transfers in the name of family members were taken advantage of, the actual ceilings reached 932 acres in Punjab, 1,120 acres in Sindh. The excess land was resumed without compensation and distributed to tenants and small owners free of cost. It also (once again) redefined the tenancy conditions and included protection against eviction.

A total of 1.3 million acres were resumed under the 1972 land reforms, of which 0.9 million acres were redistributed to tenants, small owners and the landless peasantry. The beneficiaries numbered 76,000. In 
the countryside, militant peasant organisations, carried away on the wave of popular enthusiasm for the radical rhetoric of "land to the tiller" espoused by Bhutto, seized lands and made the very entry of landlords in some areas difficult.

During its tenure, the regime of $\mathrm{Z} A$ Bhutto gradually but inexorably betrayed its true class character. It abandoned the peasantry in favour of the landlords, opening the doors of the ruling PPP for its erstwhile 'targets'. By 1976, the landlords had moved back into their areas with a vengeance, evicting by force and the support of the local administration tenants who had seized land or even those who had legally received it under MLR 115. Feudalism, far from being eliminated, was stronger than ever.

In 1977 , as a populist sop in anticipation of the coming elections, Bhutto promulgated a Land Reforms Ordinance on January 5, 1977. This Ordinance reduced the ceiling to 100 acres of irrigated land and allowed compensation to landowners through government bonds. Distribution among tenants, small owners and the landless was again to be free of cost. An additional area of 1.8 million acres was resumed under the 1977 Act, of which 0.9 million acres were distributed among 13,143 persons.

Despite the fact that Bhutto's land reforms appear to be more radical than Ayub Khan's in terms of lowered ceilings and fewer exemptions, the net effect of both reforms was marginal at best.

That is where the story of land reforms in Pakistan has stalled. Land ownership concentration has hardly changed despite all the volumes of paper expended on studying agrarian questions and the three land reforms promulgated. This can be gauged from the fact that the latest information at hand indicates that I per cent of the landowners own 26 per cent of the land even today. The power of the landlord over his tenants continues unbroken. Tenancy protection measures provide no succour to the peasantry.

Feudalism is alive, intact and kicking. Further, its educated scions (trained in the best universities the West has to offer) are today engaged in a massive PR exercise to convince the uninformed that no such creature as feudalism exists any longer in this country. The most theoretically advanced ideologues of the feudal lobby, in recognition of the fact that the world has changed and their interests today have to be pursued by different means, are positing new theories concerning what ails agriculture and how to correct it (of course, shudder the thought, without any mention of the dreaded words, land reform). 


\section{The unfinished agenda}

Let us cast a glance at the skewed land ownership patterns which persist even today in Pakistan and constitute perhaps the greatest obstacle to modernisation of economy and society. According to the Planning Commission, land has become the critical constraint in agricultural productivity and progress. The constraint can only be understood if we recall that a vast body of literature and studies now exists to show that there is an inverse relationship between farm size and productivity. That is to say, economic holdings of a size that can be self-cultivated, logically are more intensively cultivated than large farms which characterise feudal holdings. In our context of course, that may not always demonstrably be the case since the small owner is unable to gain access to credit and timely inputs of water, which are diverted because of their influence to the feudals (and feed the mountain of default of agricultural loans), and the modern technological inputs of chemical fertilizers, pesticides, etc, at affordable prices (subsidies on these items have been progressively reduced if not done away with).

In any case, there are definite indications that a polarisation in the distribution of farm size has been underway over many years. At the two poles of land holding distribution, larger farms and those of a subsistence or even smaller size have been growing in numbers. The middle distribution of small owners and tenants has been shrinking. The data suggests that the process which originated in the green revolution of the 1960s, and saw growing landlessness of the peasantry between 1961-73, driving 794,042 peasants into wage labour ( 43 per cent of the total agricultural labourers in 1973), has accelerated. Large landowners are resuming lands from tenants (and buying out small owners?) whenever and wherever possible, with a view to self-cultivation through mechanised means. The proletarianisation of the poor peasantry is therefore proceeding apace.

The latest figures available for the distribution of land holdings are provided by the Census of Agriculture, 1990, as tabulated in the Economic

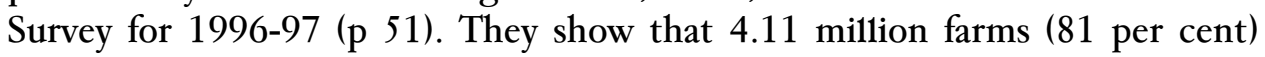
of a total of 5.01 million farms were of a size under 5.0 hectares (under the subsistence size of 12.5 acres; I hectare $=2.47$ acres). They comprised 7.43 million hectares in area ( 39 per cent) of a total farm area of 19.14 hectares. The farms of 5-20 hectares sized 2.5-50 acres, 50 acres being the size of an economic unit) comprised 0.86 million farms $(17$ per cent of the total number), and covered in area 7.16 million hectares $(38$ per cent). The balance of farms over 20 hectares in size numbered 0.11 million (barely 2 per cent of the total number) and covered 4.55 million hectares in area (24 per cent of the total area). In other words, at one end of the pole, 81 per cent of farmers owned 39 per cent of the land, while at the other pole, 2 
per cent of large landlords owned 24 per cent. In the (shrinking) middle, 17 per cent of farmers owned or leased 38 per cent of the total land area.

Past reforms from the top have clearly failed to dent the power $\mathrm{c}$ the landlords. The feudals are now preparing to be rescued by the marriage between the industrial and feudal classes on a platform of capitalist style free market ruination of the small owner and tenant by eviction off his parcel of land. What then, is the alternative for the deprived and poor peasantry, which may offer it the only hope?

\section{The need for an agrarian revolution}

We have dealt with the historically evolved pre-colonial land tenure system, the colonial encounter and its far-reaching impact as a result of introducing private property in land and a network of canals and irrigation works to provide perennial irrigation, which brought about a veritable revolution in agricultural production and at the same time created the new classes of feudals and yeoman peasantry. We then mentioned the numerous studies of agriculture over many years, traced their commonality of recommendations in terms of restricting land holding and providing protection to tenants and the rural proletariat. The three land reforms, the first under Ayub and then two more under Zulfikar Ali Bhutto, were subsequently examined from the point of view of their marginal effect on land ownership concentration and their inability to break the back of feudalism (an aim not always explicitly stated, sometimes denied, and other times subverted in practice). Last but not least, we had explicated the 'modern', capitalist style solutions now being expounded by the advanced ideologues of the feudal lobby to preserve their dominance in new forms.

The underlying thrust of the much needed, but arrested, agrarian transition in our society is in the direction of the development of capitalist agriculture. However, this is not the feudal-capitalist (an inelegant term but which describes accurately the current trend amongst our advanced feudal lobby) agriculture beloved of our latter-day converts to agri-business', but a complete and thoroughgoing agrarian transformation which eliminates feudalism with its 'absentee' inefficiencies and conspicuous consumption characteristics, root and branch. The present day relations of production in agriculture, i.e. the class relationships which dominate rural life, based on the concentration of land ownership and consequent political, economic and social power of the big landlords in the countryside, have become fetters on the further progress of the sector. Without breaking the back of feudalism by taking away the unearned income from large landholdings of the big feudals, production, productivity, yields, none of these will see radical improvement. 
118 The Lahore Journal of Economics, Vol.2, No.2

An agrarian transition from below, based on a radical re-distribution of land to the landless, poor and small peasants, would not only ensure intensive cultivation and increased productivity by an enthused peasantry, it would also bring about a breaking of the feudal political and social fetters that bind Pakistani society. A liberation of the peasantry along these lines could not but cause a transformation in the objectives and practice of Pakistani society as a whole. It would be a blow for freedom for the people as a whole. 